\title{
JEZIK GOVORA, JEZIK PESMI \\ MED NAREČJEM, NADNAREČJEM IN STANDARDNIM JEZIKOM
}

\section{MARJETKA GOLEŽ KAUČIČ}

V̌̌lankuje obravnavano jezikovno preklapljanje iz narečja v nadnarečje oz. standardni jezikv treh položajih rabe jezika $v$ folklornem dogodku. Ta označuje razmerje med petjem pesmi, govorom med informatorjem ali informatorko in spraševalcem ali spraševalko ter prilagajanje obeh različnim govornim položajem $v$ dogodku. Ugotovitve temeljijo na analizi treh variant ljudske balade "Samomor nune" iz treh narečnih okolij in ene molitve ter analize govora. $\mathrm{Ob}$ tem avtorica razpravlja še o simbolnem pomenu rabe jezika $v$ jezikovno-socialnem položaju ter vprašanju identitetne rabe obravnavanih jezikovnih kodov.

Ključne besede: jezik, narečje, nadnarečje, standardni jezik, konvergenca, ljudska pesem, identiteta, prestopanje jezikounih kodov
The article discusses the language switching from dialect to supra-dialect / standard language in three positions of language use in a folklore event, which represents the relationship between the singing of a song, the speech between the informant and the scholar and the adaptation to the different speech positions of both participants in the event. Author finds this on the basis of an analysis of three variants of the folk ballad "Suicide of a Nun" from three dialect environments and one prayer, and an analysis of speech. He also discusses the symbolic meaning of the use of language in the linguistic and social situation and the issue of the identity use of an individual language code.

Keywords: language, dialect, supra-dialect, standard, convergence, folk song, identity, switching language codes

\section{UVOD}

Namen tega članka je, da na podlagi spoznanj folkloristike, sociolingvistike, etnologije in antropologije ugotovimo, kakšno je prestopanje ali preklapljanje iz narečja v nadnarečje ali standardni jezik v treh položajih uporabe jezika v folklornem dogodku. Slednji označuje razmerje med petjem pesmi, (po)govorom med informatorko ali informatorjem in spraševalko ali spraševalcem ter prilagajanje obeh udeležencev govornim položajem v dogodku. Ob tem razpravljamo še o simbolnem pomenu rabe jezika v določenem govornem položaju, o razmerju med ustnim in pisnim kodom pesmi ter o identitetni rabi jezikovnega koda.

Tezi premisleka sta, da gre v folklornem dogodku (terenskem snemanju) za različne komunikacijske prakse udeležencev in da je ljudska pesem, ki je sinkretična celota melodije in besedila ter ritma in ritmične sheme, besedilno bolj naslonjena na knjižni kod, medtem ko je pogovor o kontekstu pesmi, šegah, funkciji, oblikovanju, življenjskih zgodbah in spominih idr., mnogo bolj oprt na narečni ali pogovorni kod. V prispevku so podani razlogi in načini preklapljanja iz enega jezikovnega koda $\mathrm{v}$ drugega.

Tekstološko-folkloristični vidik prestopanja/preklapljanja med jezikovnimi kodi vidimo tudi kot kulturno-antropološki problem predvsem v tem, da z opazovanjem izbire jezikovnega koda nosilca spoznavamo njegovo povezanost $\mathrm{z}$ ožjim in širšim družbenim okoljem, $\mathrm{v}$ katerem posamični folklorni dogodek vpliva na izbiro jezikovnega koda, pri čemer je raba 
jezika tudi instrumentalizirana (Bauman, 2002: 94; Watt, 2010). Ob tem domnevamo, da raba narečja/pogovornega jezika ali standarda govori o identifikaciji z okoljem, ki ga označuje izbrani jezikovni kod; s tem se vzpostavlja posameznikova lokalna, regionalna ali nacionalna kolektivna identiteta, kakor jo določa jezik.

Članek temelji na analizi zapisov iz terenskih zvezkov in izbranih terenskih posnetkov ter ugotovitev o posamičnem narečju, njegovi idiomatski strukturi in morebitnih vplivih tudi na vsebino pesmi, ob upoštevanju vsakokratnega konteksta. Ob tem poskušamo zaznati tudi različne vplive (jezikovne, položajne) spraševalca na informatorja na jezikovni položaj kot tudi nasproten proces in vsakokratne jezikovne in družbene konvergence in divergence (Auer, Hinskens, Kerswill, 2005).

\section{FOLKLORA IN NAREČJE, POGLEDI NA NAREČJE}

Folklorist Benjamin Albert Botkin (1949) je poudaril, da je folklora vedno regionalna oziroma del neke skupnosti, Luise Pound (1945) pa, da se ljudska govorica in narečja lahko začnejo na več načinov, iz različnih virov, obstajajo med različnimi plastmi prebivalstva in v različnih pokrajinah ter niso rezervirana samo za skupine na dnu družbene lestvice. Folkloristi tako $v$ evropskih in svetovnih nacionalnih tradicijah poudarjajo intrinzično razmerje med folkloro in narečjem. J. D. A. Widdowson je menil, da so nedvomno tesne povezave med "vernakularnim jezikom» in kulturnim izročilom (2012 [1987]: 43). Pound (1989) je tudi poudarila, da je lahko narečje predmet študij iz različnih izhodišč, npr. geografskega, družbenega, celo tehničnega. Narečje uporabljajo tudi pesniki, npr. Robert Burns (Pound, 1945: 152), pri nas France Prešeren, ko se približujejo folklori, vendar ima narečje v umetnostnem jeziku drugačno funkcijo in ni spontani akt, temveč intencionalno dejanje. To vidimo tudi pri več slovenskih književnikih, npr. pri Prežihovem Vorancu, Mišku Kranjcu, Marjanu Tomšiču, Dušanu Čaterju (Jakop, 2019: 205-206).

Intrinzičnost razmerja med folkloro in narečjem pa se poruši, ko t. i. nosilci folklore izvajajo sinkretično enoto ljudske pesmi in s tem umetnostni žanr. Ob petju ljudske pesmi začnejo uporabljati nadnarečni kod, a ohranjajo posamične narečne besede, ki kažejo na narečno geografijo in lahko vplivajo tudi na spremembo semantike. Jezik ljudske pesmi je tako vmesna stopnja med narečjem in knjižnim jezikom (Jakop, 2007; Stanonik, 2007). Ta vmesni kod - tu ga imenujemo nadnarečje ${ }^{1}$ - nekateri dialektologi imenujejo jezikovna varieteta ali različek (Bitenc, Kenda-Jež, 2015), a le v govornem položaju.

1 Torej ne kot krajevni ali pokrajinski govor, temveč kot vmesno stopnjo med nestandardizirano in standardizirano jezikovno normo. Opazujemo ga v petju in tudi v zapisu pesmi po transkripciji, medtem ko je v govoru opazna bistvena večja narečnost, a tudi krajevni govor. To ni jezikoslovna razvrstitev, temveč folkloristična, ki upošteva rabo jezikovnega koda v umetnostnih in neumetnostnih besedilih, $\mathrm{v}$ vezanem in nevezanem govoru. 
Raziskovalci so v preteklosti večinoma obravnavali vitalnost narečij ali celo njihovo počasno umiranje (Røyneland, 2009; Vandekerckhove, Britain 2009), razmerja med narečjem in knjižnim jezikom (Omdal, 1995) in prestopanja med jezikovnimi kodi (Blom, Gumperz, 1972; Gumperz, 1977). Raziskovali so jih z vidikov antropološke lingvistike (Boas, 1925; Foley, 1997; Salzmann, 1998 ), sociolingvistike (Meyerhoff, 2011; Šabec, 2016) in metodološkega prepletanja med kvantitativno analizo govora in kvalitativno analizo podatkov (Bitenc, 2016). William Labov (1966) se je npr. ukvarjal z jezikovnimi variacijami. Jezik kot obliko dejanja je preučeval John L. Austin (1990 [1962]), s kontekstualnimi dejavniki v rabi jezika so se ukvarjali Teun A. van Dijk (1977), Penelope Brown in Stephen Levinson (1978) in William F. Hanks (1987); različne vzorce govora sta raziskovala Labov (2013) in Johua Waletzky (Labov, Waletzky (1967); z govornimi dejanji, izvedbami in govornimi skupnostmi pa Ruth Finnegan (1969) in John H. McDowell (1979). Slednji je preučeval tudi socialni vidik uporabe jezika in menil, da je jezik v folklori "pesniška obdelava in ima retorični vpliv« (McDowell, 2018: 2). Aleksander Dmitrijevič Duličenko (1981) je za narečje uporabil izraz mikrojezik, skladno s tem je knjižni jezik makrojezik (prim. Šekli, 2015; Golež Kaučič, 2020). Narečje je bilo obravnavano tudi kot razsežnost individualne in skupne identitete (Giddens, 1991), v prestopanju z globalne na lokalno raven (Robertson, 1995).

Folkloristika kot ekspanzivno področje raziskav je odkrila, da raziskave povezanosti folklore in narečja lahko odgovarjajo na vprašanja o lokalnem ali standardnem idiomu, ravneh uporabe, spremembah v sprejemanju, nadomeščanju drugih standardnih form jezika, ali pa raziskuje razmerja med narečjem in knjižnim jezikom v folklori (Pound, 1945, 1989; Botkin, 1949; Fine, 1983; Widdowson, 2012). Prav tako obravnava tudi povezavo med narečjem in folkloro kot geolingvistično in folkloristično (Voigt, 1995) ali kot etnolingvistično vprašanje, pri čemer opazuje narečje kot umetnost govorjenega jezika (Stanonik, 2007). Ugotavlja, da je narečje, ki v folklornih besedilih vstopa v knjižni jezik, nekakšen alternativni diskurz v primerjavi s knjižnim jezikom kot dominantnim diskurzom (Watt, 2010). Narečje kot jezikovni fenomen so raziskovali v različnih govornih položajih in zvrsteh jezika, redko pa tudi v sinkretizmu jezika (besede) in glasbe (List, 1963).

Na Slovenskem je vprašanje o izbiri jezikovnega koda med knjižnim jezikom in narečjem v ljudskih pesmih postalo zanimivo šele z institucionalizacijo folkloristike oziroma po 2 . svetovni vojni, ni pa bilo deležno podrobnejših obravnav. Na narečje v nekaterih ljudskih pesmi so opozorili posamični poudarki v monografskih obravnavah ljudsko-pesemskega izročila (Kumer, 1996, 2002), narečnost pa je bila zajeta tudi v teoretskih obravnavah jezika v slovstveni folklori (Stanonik, 2001, 2007). Parcialna obravnava narečnih razlik v ljudsko-pesemskem izročilu je bila opravljena ob monografski izdaji družinskih pripovednih pesmi (Jakop, 2007). 


\section{JEZIKOVNO KODNO PREKLAPLJANJE IN KOMUNIKACIJSKO PRILAGAJANJE TER SOCIALNI VIDIK RABE JEZIKOVNEGA KODA}

Folkloristi jezikovne kode vidimo od znotraj, v interakciji s pevcem in pripovedovalcem, $\mathrm{v}$ njegovem naravnem govoru in naravnem prestopanju iz govora v petje (prim. Ivančič Kutin, 2011). Ko se je Dell Hymes ukvarjal z jezikom v družbi, je menil, da je folkloristika "mnogo bolj kot druge discipline primerna za preučevanje 'kreativnih aspektov rabe jezika'« (Hymes, 1971: 49). Trdil je, da lahko veliko prispeva s sledenjem »družbenim in ekspresivnim vidikom govora, " in to z delom od znotraj, začenši "z opredelitvami skupnosti o položaju, dejavnosti, namenu, žanru« (Hymes, 1975: 350). Cilj etnopoetičnega besedila je pokazati, kako tehnike enkratnih ljudskih izvajalcev povečujejo estetsko vrednost njihovih predstav v njihovih specifičnih kulturnih kontekstih. Folkloristi, ki so se ukvarjali s folklornim dogodkom in jezikom dogodka, so preučevali akt jezika v kontekstu dogodka (gl. prispevke Rogerja D. Abrahamsa, Barbare Babcock, Garyja Gossena in Joela Scherzerja v Bauman, 1978), vendar so bili večinoma pozorni na besedno, ne pa tudi na peto folkloro.

Govorno in komunikacijsko prilagajanje jezika je v folklori vidno v različnih govornih položajih in poetskih žanrih, pa tudi pri govorcih, ki ob snemanju pesmi prestopajo iz enega $\mathrm{v}$ drug jezikovni kod. O tem govori teorija govornega/komunikacijskega prilagajanja: konvergenca vključuje jezikovno poenotenje, fokusiranje in homogenizacijo jezikovnega repertoarja, tudi pri tradicionalnih narečjih, divergenca pa povečevanje raznovrstnosti, naraščajočo razpršenost in heterogenizacijo (Auer, 1998; Auer, Hinskens, 1996; Bitenc, 2016: 55). Peter Auer in Frans Hinskens sta ugotovila, da v večini držav (zahodne) Evrope prevladuje tip $\mathrm{C}$ - diglosija, tj. bolj ali manj porazdelitev vmesnih različic med standardnim jezikom in (osnovnim) narečjem - standardni/narečni kontinuum (Auer, Hinskens, 1996; gl. še Røyneland, 2009: 9). Ta tip označuje izravnavanje razmerja med narečjem in standardnim jezikom in celo distribucijo variant med standardom in osnovnim narečjem - tj. t. i. regiolekt ali regionalno narečje. Je to lahko nadnarečnost, ki jo lahko opazujemo v petju ljudske pesmi? Morda. Ker je Auer preučeval te sheme le v govoru, lahko rečemo, da je sprememba komunikacijskega kanala iz govora v petje mnogo korenitejša kot le sprememba v govornem položaju.

Jezikovno prilagajanje lahko zajema tudi preklapljanje med različnimi kodi (narečje, jezikovne različice, pokrajinski govor) ali kodno mešanje (prim. Gumperz, 1977; GardnerChloros, 2009). Izvira pa iz vsakokratnega konteksta (npr. petje, govor, pripovedovanje, pogovor, dialog v folklornem dogodku idr.), zato je ta eden izmed dejavnikov, ki odločilno vpliva na izbiro jezikovne različice. Poleg tega pa, "[t]ako kot kontekst vpliva na jezikovno izbiro, tudi izbira jezika vpliva na socialnopsihološko situacijo oz. kontekst: jezikovne izbire so tako kazalnik našega zaznavanja konteksta, obenem pa spreminjajo pomembne značilnosti tega konteksta« (Edwards, 2009: 30; prim. Bitenc, 2016: 57). ${ }^{2}$

2 Hinskens navaja tudi izravnavanje narečja, izgubo ali premik oziroma obrat narečja (Auer, Hinskens, Kerswill, 2005: 11). 
Z analizo govorno-petega diskurza lahko spoznavamo družbene komponente v samem folklornem dogodku, neenakost v diskurzu, morebitno nadrejenost spraševalke ali spraševalca ali pa njuno prilagajanje ter tudi vprašanje statusa obeh udeležencev v intervjuju (van Dijk, 2008; Ule, 2009a: 122). Vprašanje je, ali sta informator in spraševalec res v enakem položaju? Z opazovanjem dogodka razbiramo okoliščine, ki jih govorci dojemajo in interpretirajo s stališča družbene moči: v folklornem dogodku in intervjuju informator ni podrejen, večinoma se podredi spraševalec, ko se prilagodi jezikovnemu položaju, saj od informatorja pričakuje pomembne podatke za raziskavo.

Pri vsakem terenskem snemanju smo pozorni na dva dejavnika, in sicer na ravni narečja, nadnarečja in standardnega jezika:

1. govorno prilagajanje

2. prilagajanje petju.

Ob tem opazujemo govorno variantnost, kompleksnost jezikovnih izbir glede na vsebino povedanega in petega (emocija, prizadetost, spomin), mešanje zavestne, podzavestne izbire govora oz. jezikovnega koda. Opazimo tudi, da je jezikovna realnost folklore ali ljudske pesmi različna glede na formalne oz. neformalne okoliščine. V formalnem položaju, ko je intervju strukturiran kot spraševanje in odgovarjanje, torej skladen z zahtevo in pričakovanjem spraševalca po petju ali pripovedovanju o folklori, je jezikovna situacija nespontana. V položaju brez snemanja pa nastane t. i. neformalni folklorni dogodek, ki je tako vsebinsko kakor jezikovno precej bolj sproščen.

Dell Hymes (1975) je opozoril, da jezik ne more biti obravnavan ločeno od socioloških in kulturnih dejavnikov, jezik je treba razumeti kot »socialni vir«. Zato v folklornem dogodku spremljamo jezikovno in družbeno situacijo, v kateri se prepletata dogodek in govorno dejanje. Statusna interakcija je interakcija dveh ali več oseb v folklornem dogodku terenskega snemanja. Imamo tekst, teksturo, kontekst, jezik, nosilca in pesem ter govor, ob tem pa je udeležen še spraševalec kot opazovalec ali aktivni udeleženec dogodka. Jezik se realizira v petju in dvogovoru, pri čemer gre za preklapljanje jezikovnih kodov, ki se prilagaja posamični situaciji. Te vidike obravnava etnografija komunikacije (Hymes, 1986 [1972]: 59-65; Johnstone, Marcellino, 2011: 61).

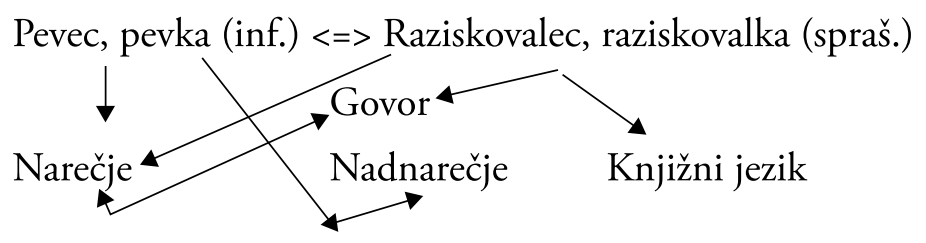

Slika 1. Interakcije med udeleženci v folklornem dogodku (pri terenskem snemanju). 
Ko na terenu raziskujemo izbiro jezikovnega koda, je pomembno naslednje: vsebina, struktura, narativnost ali petje; interakcija v dialogu med spraševalcem in informatorjem; kontekstualna situacija in jezikovni kod spraševalca. Vsi ti parametri se lahko med seboj povezujejo in oblikujejo mrežo, s katero je mogoče določiti, kakor govorke in govorci, pevke in pevci prestopajo/preklapljajo iz koda v kod ali ustvarjajo mešanje jezikovnih različic $\mathrm{v}$ pesmi, govoru, petju.

Jezik ima lahko povezovalno moč, lahko pa tudi odtujevalno. V izbiri jezika odsevata socialni in kulturni kontekst. Imamo torej tri ravnine: govor ali pogovor, petje in kontekst, ki je kontekst izvedbe, in socialni kontekst.

Auer je postavil naslednji vprašanji:1. Kakšni so jezikovni in socialni kodi v kodnem preklapljanju?

2. Kako se pogovorno preklapljanje jezikovnih kodov nanaša na njihov širši etnografsko rekonstruiran družbeni in kulturni kontekst? (Auer, 2002: 2-3).

Dodajamo še eno: Kako petje narekuje uporabo jezikovnega koda?

Ob analizi primerov bomo odgovorili na ta vprašanja in še, ali se v srečanju med informatorjem in raziskovalcem primeri tudi prestopanje iz izrazitega narečja v bolj knjižni jezik, bodisi zaradi lažjega razumevanja ali pa ker informator vstopa v drugačno razmerje, kakor ga je vajen v vsakdanjem dvogovoru? In, ali se tudi raziskovalec v dialogu z informatorjem približuje njegovemu narečnemu govoru, ko morda uporablja značilne narečne besede, da bi se mu približal na čustveni ali celo identitetni način.

\section{IDENTITETA, SPOMIN IN NAREČJE}

Družbena situacija, v katero vstopa nosilec folklore, vpliva na izbiro jezikovne zvrsti. S tem afirmira nacionalno ali lokalno pripadnosti tudi z jezikom, ko poudarja teritorialnost in se sklicuje na preteklost. Temeljni koncepti graditve lokalne identitete so nedvomno povezani $\mathrm{z}$ vnosom narečnih izrazov v pesem, medtem ko sta oblikovanje nacionalne identitete in samorefleksija (Smith, 2005; Castells, 2010) povezani s strukturo jezikovnega izražanja v pesmi, ki se oddaljuje od čistega narečja in se približuje knjižnemu kodu. Pri obeh je vidno izražanje kolektivne identitete in ohranjanja kolektivnega spomina (Halbwachs, 2001 [1950]). Skupinska zavest o lokalnem je identifikacija z lokalnim prek narečja (pogovor, spomini, razmišljanja), skupinska zavest o nacionalnem pa je identifikacija z nacionalnim prek nadnarečja (petje pesmi, folklora kot duša naroda). Po mnenju Alana Dundesa je »[f] olklora [...] morda najpomembnejše sredstvo za sporočanje simbolov skupine« (Dundes, 1984: 150), po Richardu Baumanu pa je »[f]olklora[...] funkcija skupne identitete« (Bauman, 1971: 32; prim Bausinger, 1977; Honko, 1980). Poleg družbene situacije folklornega dogodka pa moramo upoštevati še, da je "vstopanje« v petje povezano s poetiko pesmi, ki sodi v umetnostno zvrst, medtem ko pride ob prenehanju petja do preklopa v drugačno funkcijsko zvrst pogovora, v sporočanje, ki se oddaljuje od umetnostne komunikacije. 
Posameznik ima lahko več identitet tudi ob uporabi narečja in nadnarečja: gre za identiteto mikrookolja, $\mathrm{v}$ katerem živi in kjer v govoru uporablja narečje ali pogovorni jezik kot mikrojezik, v petju pa preklopi na nadnarečni jezik; tako se bliža standardnemu jeziku etnije, torej eni od razsežnosti etnične identitete (Phinney, 1991; Helms, 1994; prim. Priestly, 2009). Pevec in govorec sta tako vpeta v lokalno kulturno identiteto (vas), tudi regionalno (sosednje vasi, pokrajina) in hkrati nacionalno (država); lokalna kolektivna identiteta je torej multidimenzionalni konstrukt (Phinney, 1991: 193), ki se prav tako spreminja in prilagaja spreminjajočemu se kontekstu (McDonald, 1986:333), npr. identiteta posameznika, kakor se izraža v domačem okolju ali pa v okoliščinah razmerja $\mathrm{z}$ raziskovalcem, ko se pevci in govorci prilagodijo lastnim predstavam o zahtevah raziskovalca. Pri tem identiteto lahko tudi prikrijejo ali pa jo z rabo narečja izrazijo le takrat, ko ne gre več za formalni odnos z raziskovalcem ali ko se iz petja pesmi kot formalne poetike premestijo v lokalni narečni govor, ki omogoča mnogo bolj spontan izražanje misli.

\begin{abstract}
V medsebojni komunikaciij [...] se sogovorci jezikovno prilagajajo drug drugemu z zmanjševanjem razlik med njihovimi govornimi vzorci in medsebojno prevzemajo značilnosti govora. Če se govorec določenemu naglasu ali varieteti prilagaja dovolj pogosto, bi tudi trdil, da prilagajanje lahko sčasoma postane stalno, posebno če so stališčni dejavniki ugodni. (Trudgill, 1986: 39)
\end{abstract}

Po modelu identitetne projekcije oz. modelu verbalnih »dejanj identitete« (Le Page, Tabouret-Keller, 1985) se izbira jezikovnega koda interpretira kot izraz družbene in osebne identitete vsakega posameznika. Ta, čeprav večinoma nezavedno, privzema ali skuša privzeti stil (narečne značilnosti), ki se mu zdi primeren za dojemanje razmerja s sogovorcem - ne prilagaja se torej nujno sogovorčevemu stilu, temveč bolj podobi samega sebe v odnosu do sogovorca (Le Page, 2008: 28). Jezikovna identiteta se lahko ohranja kljub tesnemu in dolgotrajnemu stiku z drugo jezikovno "varieteto" oz. njenimi govorci. Npr., ko se kdo $\mathrm{v}$ mejah Slovenije poroči v drugo narečno skupino, še ne pomeni, da je v celoti prestopil vanjo: prilagodi se sicer novi narečni stvarnosti, vendar ob srečanju z govorci prvotne narečne skupine takoj spregovori v tem narečju (prim. Stanford, 2008). To je t. i. odpornost proti socialnemu vplivu (Ule, 2009b: 300). Različne medvarietetne oblike pri jezikovnem prilagajanju imamo lahko za rezultat številnih strategij kodnega preklapljanja in kodnega mešanja, opazujemo različne dimenzije nevtralnosti s kombinacijo različnih varietet, npr. narečje, nadnarečje, standard, drugo narečje; zato se lahko ustvari dvojna socialna in dvojna ali večjezikovna identiteta.

Družbena in jezikovna identiteta sta tesno povezani s spominom. Spomin v folkloristiki v tem kontekstu interpretiramo glede na družbeno okolje posameznikov, pevcev. Ti ob improvizatoričnem ustvarjanju variant vključujejo narečno podobo lastnega lokalnega območja in s tem vključujejo individualni spomin v kolektivno zavest, hkrati pa z uporabo narečnih besed krepijo kolektivno identiteto območja. Narečja imajo tako pomembno 
družbeno vlogo v sooblikovanju kolektivne identitete. Tudi intelektualec, ki za svojo komunikacijo uporablja knjižni jezik, v svojem mikrokozmosu (regija in kraj, od koder izvira) začne uporabljati narečje ali splošni pogovorni jezik. ${ }^{3}$

Tudi simbolna identiteta (zamišljena ali realna; Hobsbawm, Ranger, 2003 [1983]) se v pesemski poetiki izraža z rabo ali nerabo narečja. Pesem je simbolno in semantično podrejena umetnostni zvrsti. Ob petju nastaja nadnarečje, ki povezuje oba jezikovna koda, $s$ tem pa se ne izgubljajo lokalne in regionalne značilnosti skupnosti, nasprotno, ko pevci pesem sprejmejo za svojo, soustvarjajo lokalno identiteto, ki se povezuje z nacionalno prav s petjem pesmi, ki je razširjena tudi drugod po Sloveniji.

\section{JEZIK PESMI, JEZIK GOVORA: \\ ETNOGRAFIJA GOVORNE FOLKLORE IN ETNOGRAFIJA PETE FOLKLORE}

Folkloristi so pri študiju narečja in nadnarečja v folklori v tesnem stiku s posameznikom in s skupnostjo in ob preučevanju žanra, izročila, umetnostnih performativnih praks razumejo jezik kot družbeni dejavnik, hkrati pa prav pri petju ljudske pesmi opazujejo spontano prilagajanje jezika umetnostni zvrsti. Prestop iz petja v govor pa omogoča, da posameznik spontano izstopi iz formalnejšega jezika v lasten, bolj spontan jezik, ki je večinoma narečje, razen kadar govorec zaradi želje po razumljivosti govori tudi knjižno. Etnografija pete folklore se spaja z etnografijo verbalnega upovedovanja folklore in spominov. Odkriva primarno in sekundarno uporabo narečja, tj. raba narečja v pogovoru o pesmi in v petju pesmi.

$\mathrm{V}$ raziskavi rabe narečja $\mathrm{v}$ folklori poskušamo tako pokazati variantnost tudi v jeziku, in ne samo v besedilih, značilnih za ljudsko pesem, saj je treba ob potovanju pesmi v variantnem nizu upoštevati tudi prestopanje iz enega narečja $v$ drugo, pri čemer pride tudi do zamenjave ali opustitve narečnih prvin. Hkrati pa želimo z različnimi jezikovnimi položaji pokazati na raznovrstno kodno preklapljanje v enem folklornem dogodku. V enojezičnem položaju je govorčeva izbira omejena na različne sloge, registre in narečja posamičnega jezika v govoru (Šabec, 1997), spremljata pa ga tudi izstop iz govorjenja v petje, pri katerem je narečje omejujeta ritem in melodija, in izstop iz neumetnostne zvrsti v umetnostno, ki zahteva jezikovno prilagoditev. V govornem položaju na informatorja vpliva naslovnik/ naslovnica (spraševalec/spraševalka), drugi dejavniki pa so še tema pogovora, razmerje med udeležencema v pogovoru, preklop iz govora o pesmi v govor o življenju, šegah, navadah idr., predvsem pa v spomine, življenjske zgodbe in drugo, kar pomeni, da se premešča iz etnografskih in folklorističnih zahtev spraševalca ali spraševalke v zgolj spremljanje spontano izraženih pripovedovanj.

3 Podobno je tudi po Evropi, kjer se krepijo težnje, da bi narečja vrnili v kulturni obtok, kajti regionalni dialekti so v vsej konsolidirani in globalizirani Evropi ogrožen kulturni vir (prim. Uppsala Institute for Dialect and Folklore Research; Røyleand, 2009). 
Z empiričnimi analizami treh variant ljudske balade skušamo spoznati ali določiti načine prehajanja iz narečnosti v nadnarečnost oz. knjižno obliko, pri čemer je opazna izrazita dvojnost: uporaba čistega narečja v govoru in njegova redukcija v petju. ${ }^{4}$,

$S$ primerjavo variant enega tipa pripovedne pesmi, kjer je vključevanje in izpuščanje narečnih besed zelo opazno, želimo ugotoviti, kako so zaradi ritma in melodije pevci iz posamičnih krajev in geografskih območij vključevali narečne besede ali jih izpuščali. Raziskava temelji na štirih primerih terenskih posnetkov iz treh različnih narečnih skupin, in sicer variantnega niza balade "Samomor nune zaradi ljubezni« (SLP 4. 1998, tip 215) in ritmizirane molitve, ki sodi v žanr nabožnih pesmi. ${ }^{5}$ Za variante pesmi iz treh krajev in pokrajin (Gorenjska, Štajerska, Primorska) ugotavljamo, da vsebinsko pesem sodi v isti tip, skupno pa jim je tudi, da vsi pevci in pevke v petju vstopajo v nadnarečje, v govoru z raziskovalcem ali raziskovalko pa izrazito kažejo narečno podobo kraja in pokrajine. Podatki so bili dobljeni na terenu, ob intervjuju z udeležbo in opazovanju. Zvočni posnetki pesmi in pogovora so bili transkribirani na način, kakor ga uporabljamo folkloristi-tekstologi, torej ne z vsemi dialektološkimi znaki, temveč poenostavljeno, z uporabo le nekaterih značilnih. Folkloristične analize narečja in nadnarečja namreč v tem sledijo etnografski metodologiji (Saville-Troike, 2004: 113; Golež Kaučič, 2001; Kumer, 2002).

$\mathrm{V}$ pesmih so pomembne tudi arhaične (narečne) besede, kar je izhodišče za jezikovno in vsebinsko arheologijo. V pesemskem besedilu lahko na podlagi narečnih besed spoznavamo historični izvor pesmi in vpetost v lokalno ali regionalno okolje. Narečne besede ustvarjajo tudi različno semantiko, zamenjava z bolj knjižnimi besedami pa lahko izraža tudi odnos do pesmi. Vprašanje je tudi, ali je pevec ali pevka in pozneje zapisovalec ali zapisovalka morda napačno uporabila ali uporabila posamične besede, ki jih ni poznal/poznala, saj je njegovo/njeno narečje lahko drugo; s tem je spontano ali namenoma spremenil/spremenila tudi pomen pesmi. Ker pa je besedilo tudi zvočni pojav (Kodrič, Tivadar, 2015), je narečna beseda $v$ nadnarečni pesmi vidnejša kot $v$ povsem narečni pesmi in jo lahko lažje identificiramo.

$\mathrm{V}$ obravnavanih variantah ljubezenske balade o nesrečni nuni so razvidne tri nadnarečne situacije, tri besedilne in vsebinske variante, melodije, ki določajo ritem in jezikovno prilagajanje besedila melodiji in spreminjanje semantike tudi z uporabo narečnih besed, ki so del lokalnega okolja. S terenskega posnetka in nato zapisa pesmi v znanstvenokritični izdaji je razvidno preklapljanje iz petja v pripovedovanje in nazaj, iz nadnarečja v narečje, in s tem spreminjanje komunikacijskih kanalov (iz petja v govor) v posamičnem folklornem dogodku in nato objava v pisnem kodu. 
A. Prva pesem je bila posneta leta 1979 v Magozdu nad Kobaridom na Primorskem in ostaja edina varianta s srečnim in ne tragičnim koncem. Govora nismo mogli neposredno transkribirati, ker pa so ohranjeni terenski zvezki, si z njimi pomagamo pri vprašanjih o historiatu pesmi, narečnem govoru v njej in o pevskih načinih.
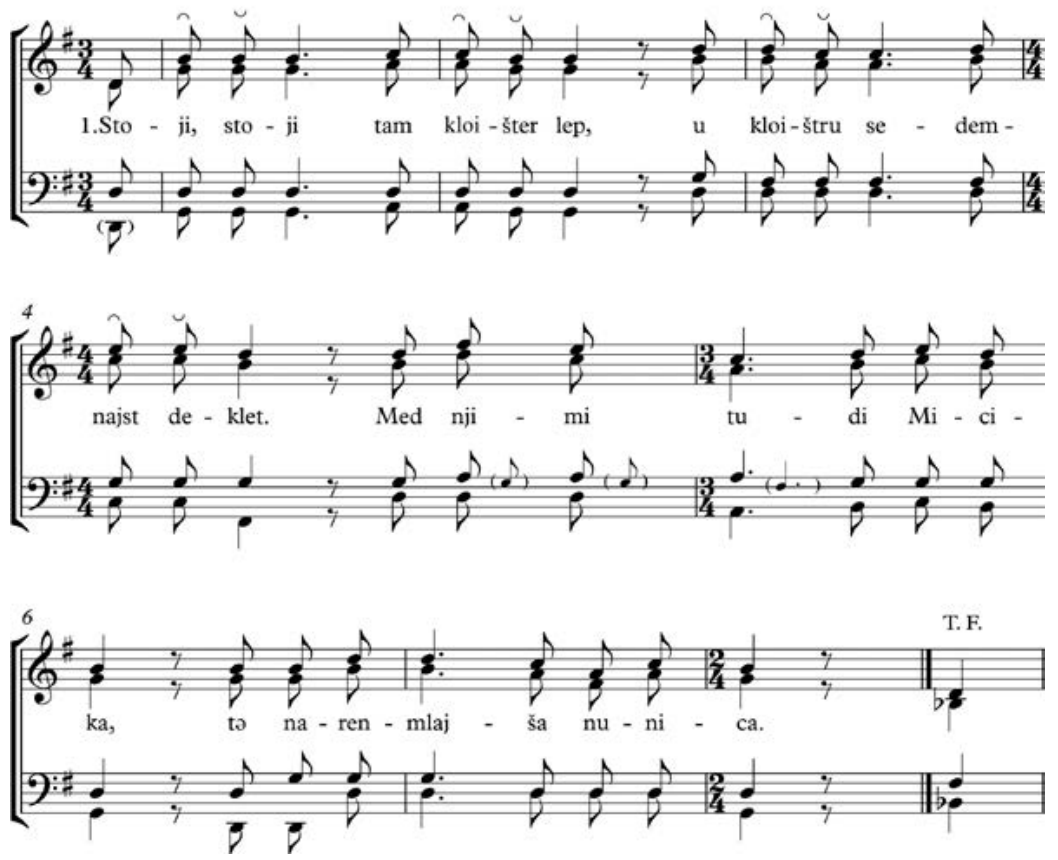

Slika 2. Notografija melodije »Samomor nune» (notografija: Teja Turk).

1. Stoji, stoji tam klo šster lep,

U klo stru sedemnajst deklet.

med njimi tudi Micika,

to narenmljaša nunica.

\section{Pod kloistrom fantič je oraw} in drobno detelco sejaw.

Skoz okno gleda Micika, ta narenmlajsi nunica.
3. Ta velka sestra jo svari:

"Nikar, nikar, oj Micka ti.

Pozabi ti na ljubega

in spomni se na Jezusa.

4. "Pustite mene zdaj domov,

za eno urco al pa pow.

I: In Micka bla je uslišana,

Ven s kloistra bla je zbrisana. :/

(Pesem 215/132, Magozd nad Kobaridom, SLP 4. 1998: 163.) ${ }^{6}$

6 Trak 979 je hidroliziran in neprimeren za poslušanje, zato smo uporabili rokopisni zapis Julijana Strajnarja. 

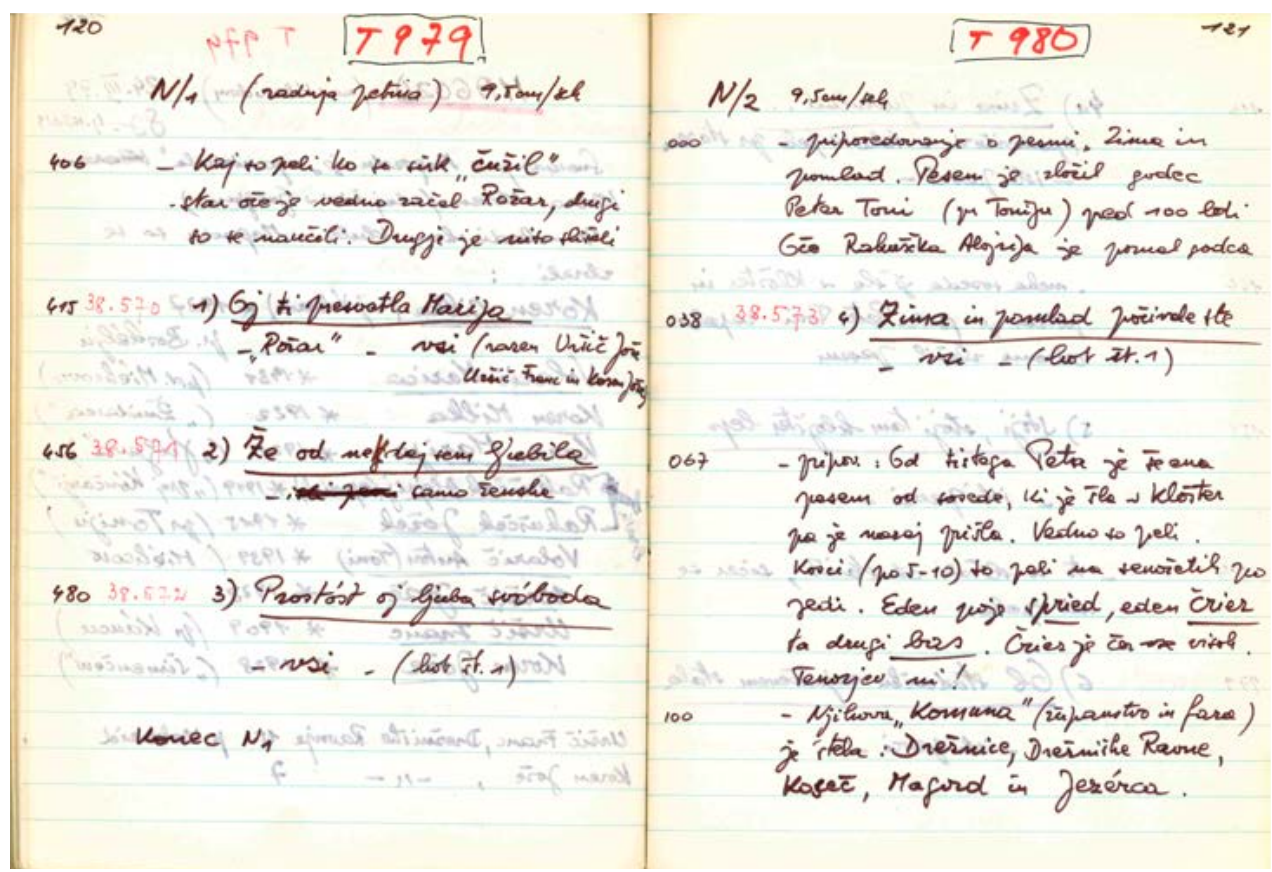
$j$ "rteba .Drèrice, Dreinithe Ravre, Kosec, Magerd in Jeréraa.

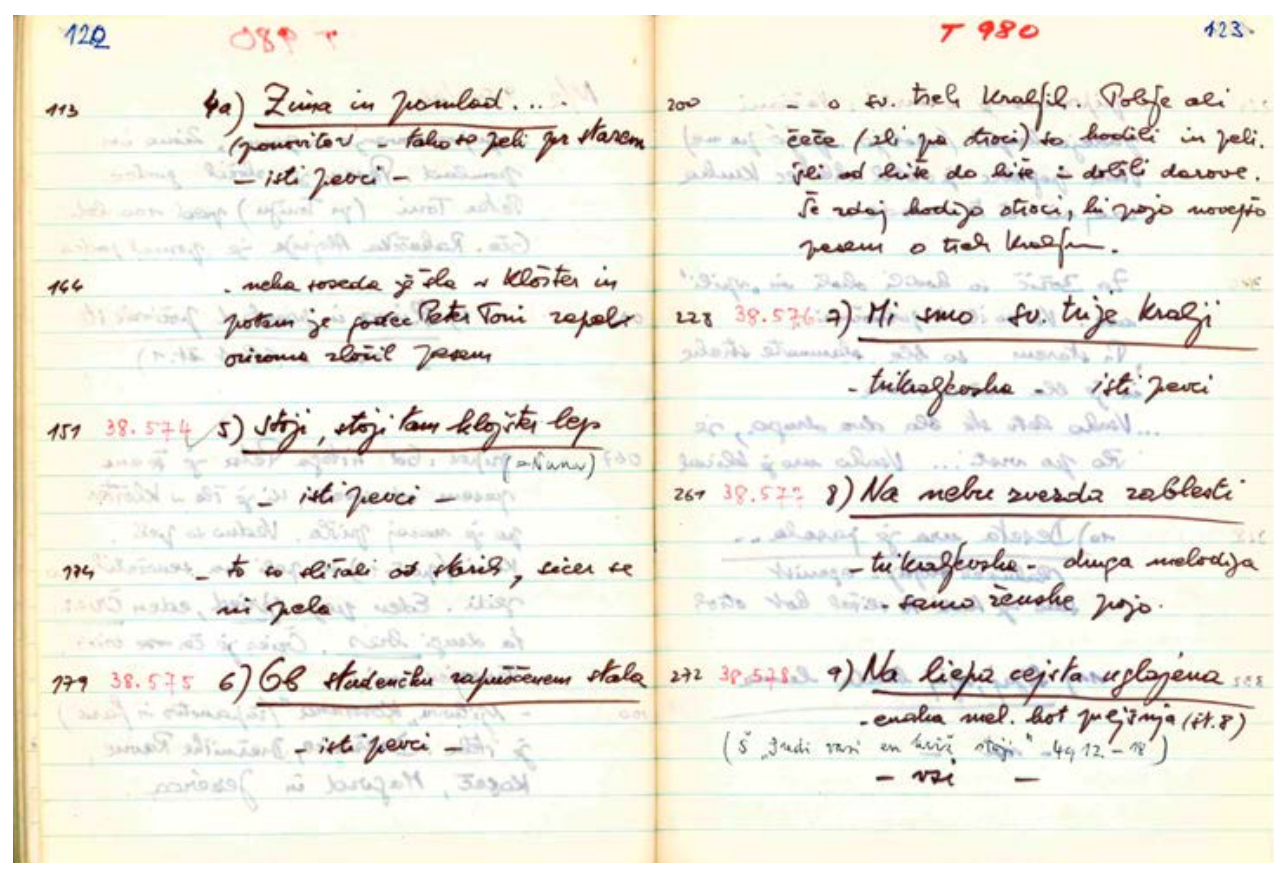

Sliki 3 in 4. Preslikavi dveh strani terenskega zvezka Julijana Strajnarja (GNI TZ JS 4: 120-123). 
Govor: Informator je dejal: „Od tistega Petra (Toni, pri Toniju) je še ena pesem od sosede, ki je šla v klošter, pa je nazaj prišla. Vedno so peli kosci (po 5-10), so peli na senožetih po jedi. Eden poje spried, eden čriez, ta drugi bas. Čriez je čez vse visok. Tenorjev ni!"

$\mathrm{V}$ pesmi je manj narečnih značilnosti, je nekaj diftongizacije, ki je značilna za primorsko narečje; v govoru je narečje izrazitejše, še posebej ob izrazih za posamične pevske položaje. Zapis pesmi, transkribiran po zvočnem posnetku, odkriva preklop iz petja, ki je $\mathrm{v}$ nadnarečju, v govor ali pripovedovanje, ki je v narečju.

B. Druga pesem je z Gorenjske.

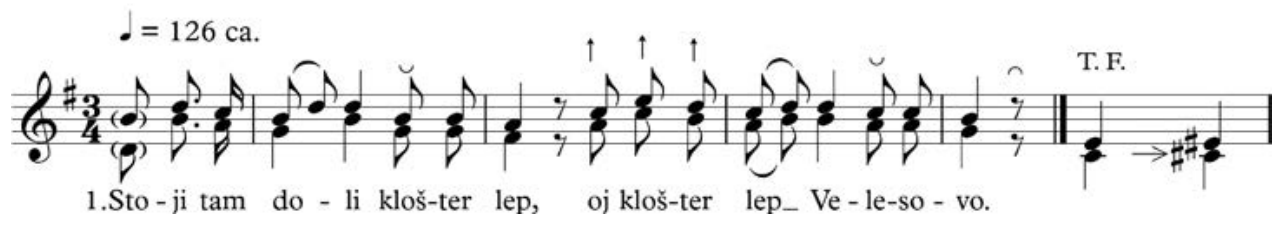

Slika 5. Notografija melodije »Samomor nune» (notografija: Teja Turk).

1. Stoji tam doli klošter lep, oj klošter lep, Velesovo.

2. U kloštru je šestnajst deklet, ta sedemnajsta Uršika.

3. Ta sedemnajsta Uršika Najmlajša nuna klošterska.

4. Po ganku je spancirala, Zlat prstan s prsta snemala.

5. Za kloštrom fantič je oraw In drobno detelco sejaw.

6. Skoz okno ga je gledala, Zlat prstan s prsta snemala.

7. "Ah, pojdi doli Uršika, da bova maw špncirala.
8. Da greva malo na špancir, da krajši nama bo večer.

9. Vsaj za_ eno urco al pa dve, da se ne utrga $u_{\_}$men srce."

10. "Le maw počakaj, fantič ti, grem drugo nuno vprašati."

11. Al nuna ji odgovori, da s kloštra ubene ne spusti.

12. Uršika je u cimer šla, najlepša nuna klošterska.

13. Prijela drobno je pero, pisala j_pismo u slovo.

14. Rožni venc prijela je, za vrata ga zagnala je. 
15. "Le naj te moli, kdor te če, jaz Uršika ne bom te več.."

16. Ostri meč prijela je, Ga v srce zasadila je.

17. Marijo je začew zvonit, $k$ molitvi jih začew vabit.

18. Al Urišike od nikoder ni, ah, Uršike od nikoder ni.

19. Uršika na tleh leži, krog nje pa teče rdeča kri.

20. Pismo je na oknu blo in zraven drobno še pero.
21. Ko j pismo nuna odpirala, glasno ga je prebirala.

22. V pisemcu pa to stoji: "Tega ste krivi, očka vi!

23. Tega ste krivi, očka vi, tega ste krivi, mamca vi.

24. Ko ste me dali v klošter svet, ko sem bla stara šestnajst let.

25. Bi me pa dali v klošter svet, ko sem bla stara šestnajst let.

26. Še nisem znala brat, pisat, nobenmu fantu odgovor dat."

(Pesem 215/147, Britof pri Kranju, SLP 4. 1998: 174).

Spraševalec se je poskusil prilagoditi gorenjskemu narečju (prim. posnetek).

Govor ene od pevk: „Od kloštra... Od Velesovskega kloštra... To je pa ud nun, ka so ble včas u Velesov. To pa je, ke so eno mlado dalo v kloštr, ka se je zaklala, ka je enga fanta spoznala [...] Melodija ni nəč fajn. ${ }^{7}$

$\mathrm{V}$ pesmi je nekaj značilnosti gorenjskega narečja (mnogo nemških popačenk - cimer, klošter, špancir; ubene namesto nobene idr.). Rabo nadnarečja narekuje tudi rima. Kakor je razvidno iz komentarja pevke, je narečje bolj poudarjeno v govoru.

Še značilnejša razlika med petjem pesmi v nadnarečju in pogovornem jeziku je v naslednjem primeru.

C. Tretja pesem, posneta leta 1986 v Mostecu pri Dobovi, je transkribirana na novo.

1. Je u kloštar šla, je nunca bla, je dol skoz okno gledala. I:Pod oknom fantič je oraw, je drobno deteljo sejaw.:I
2. "Le pridi doli Uršika, najlepša sestra kloštarska. I: Da bom od tebe slovo jemaw, zlat prstan ti za stavo daw«.:/

7 Gre za fonetično transkripcijo, ki ni dialektološko natančna, je pa kazalka narečja. Več o natančni fonetični trankripciji gl. Kenda-Jež, 2011; Bitenc, 2016: 316. 


\section{3. "Tega ste krivi mamca vi,}

ki ste me u klôstar silili.

I: Še nisem vedla, kaj je svet,

zdaj moram za ljubezen vmret«.:/

(Arhiv GNI M 43.447, GNI T 1433-18/207 in 18/211, posnela: Marjetka Golež in Marko Terseglav, 1986; transkripcija melodije: Teja Turk; transkripcija besedila: Anja Moric in Marjetka Golež Kaučič).

Mostec pri Dobovi (GNI M 43.447)

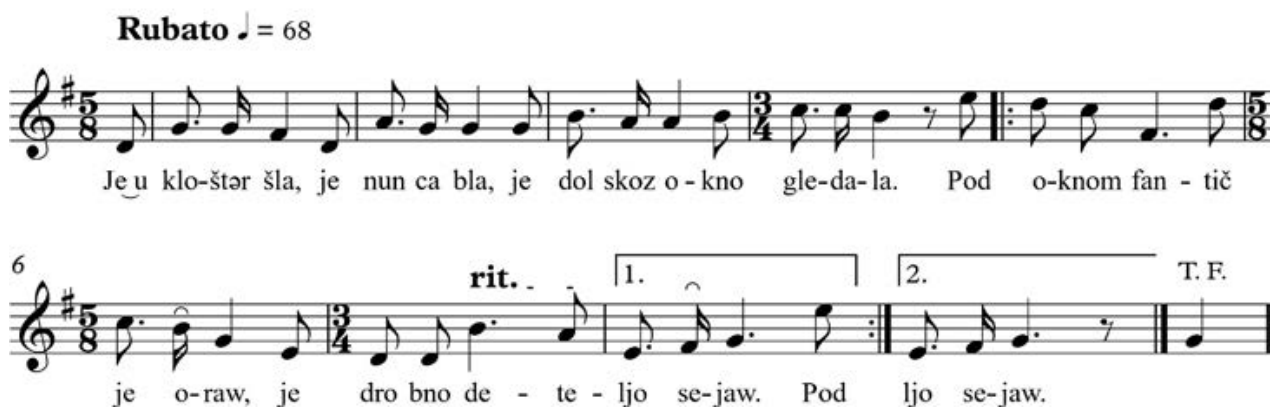

Slika 6. Notografija melodije »Samomor nune» (notografija: Teja Turk).

Govor: Spraševalec se je z uporabo pokrajinskih narečnih besed poskušal približati pevki, npr. z izrazom popevati (peti). To razmerje prilagajanja ali konvergence (Bitenc, 2016) prispeva $k$ recipročnemu razmerju med informatorjem in spraševalcem (Rusell, 2006: 15). Skratka, ustvarja se razmerje, v katerem ni premoči enega nad drugim (Sahlins, 1999 [1972]) ali neprimernega pokroviteljskega odnosa spraševalca do informanta. Raziskovalec je senzibilen in odprt do pevke (Abrahams, 1970; Glassie, 1982), omogoča ji prost govor o spominih, življenjskih zgodbah, izraženih v najpristnejšem in živem govoru - narečju. Pri tem pa sledi svoji poklicni integriteti, ko vztraja, da mu informator pove, kar potrebuje za raziskavo (Dundes, 2005). V tem pogledu je terenska raziskava dinamičen dogodek, razmerje med dvema ali več udeleženci s svojimi lastnimi razmišljanji, besedili in kontekstom (Toelken, 1996: 16). Šele tako lahko zaznamo premeščanje med jezikovnimi kodi, jezikovno divergenco in konvergenco. In prav takšno situacijo odkrivamo v tem primeru.

Pevka je imela pesmarico, zvezek s seznamom pesmi, vanj je zapisala pesmi, da jih ne bi pozabila, med drugimi tudi tri kitice pesmi o nuni, ob kateri je pripisala, da je stara. Naučila se je je od očeta in sester. Pevka je torej uporabila tako pisni kot ustni kod.

Ko je pršu $k$ men Tone, so ga napat in je dubu z latom po glavi. In on je reku, da bi lahko enga fejst nazaj fdaru, al ga j prepoznal in rekel: "'Drago, tebe pa nečem!«' In drügo jütro, se pa ga zgrevalo, da se on ni postavu nič u bran, je pa zajahu koñja - to je blo glih na nedeljo vjütro in je šew tam do vsacga posameznega, jih še na postelji 
dobu in je jemu obračun, kakof jast ne vem. In ko je šew mimo naše hiše - jest sem bla tud še na postelji - pa reče oče: "Reza, Toporišče poba jaše koñja te po vas!«' No in on je mimo nas jahal tam do tistga Dragota, pa ga je malo stresew (smeh). No in od takrat ga niso več ustavljal, tako da je lahko hodu $k$ men $v$ vas.

Ko je govorila o osebnem doživljanju ali spominu na mlada leta, ko je njen bodoči mož pri njej vasoval, je emocija narekovala izbiro jezikovnega koda. Pevka se je z evokacijo osebne preteklosti izražala mnogo izrazitejše narečno kot sicer v pogovoru, ko se je v formaliziranih okoliščinah terenskega snemanja prilagajala govornemu in pevskemu položaju.

V opisu folklornega dogodka in spoznavanja rabe narečja ali nadnarečja, uporabljamo različne parametre (upevanje, načini petja, povezovanje med pevci in pevkami, občinstvom idr.), ki kot "način govorjene [pete, op. avt.] verbalne komunikacije vključuje domnevo odgovornosti do občinstva za izkazovanje komunikacijske kompetence» (Bauman, 1975: 293). V folklornem dogodku sta formalizirana govor in petje, ker to ni neformalna situacija, saj gre večinoma, a ne vedno, za napovedani dogodek s sodelovanjem vsaj dveh udeležencev. Se pa etnografija govora in petja med seboj razlikujeta, ne samo v izbiri jezikovnega izraza: pri petju gre za pesniški izraz, ki sodi v umetnostno zvrst $\mathrm{v}$ nasprotju z govorom, ki sodi $\mathrm{v}$ splošno sporazumevalno zvrst, zato je $\mathrm{v}$ njem manj metafor in figur kot v petju.

Tudi v tem obravnavanem folklornem dogodku vidimo jezikovne variante in vpliv družbenega okolja na govor. Opazujemo lahko "prepletanje jezikov, narečij in idiolektov v zapletenih sodobnih družbah" (McDowell, 2018: 8), pa tudi sicer lahko v vsakem govornem položaju dveh ali več udeležencev vidimo "produkcijo govornih taksonomij, ki opisujejo načine govora v skupnosti glede na slogovne konvencije in družbene priložnosti« (Sherzer, 1983: manjka stran navedka). Pevka je v formalnem pogovoru tudi izrazila svoj pogled na jezik svoje skupnosti, češ da gre za mešanje slovenščine in hrvaščine, ker je ta kraj ob meji s Hrvaško.

Kompleksna preučitev vzvodov rabe jezika in njegovega vpliva na vsebino folklornega žanra, saj verjetno semantika (pomen) narečne besede vpliva tudi na individualno razumevanje pesmi kot tudi in v razgrnitvi kulturno-antropoloških elementov. Ti so bili odločilni pri uporabi oz. cenzuri narečja. Vse to kaže na zelo zapleten proces jezikovnega kodnega preklapljanja in vsebinske različnosti posameznega tipa znotraj enega žanra. Tokrat smo preučili balade, podobne ali pa povsem drugačne rezultate pa je mogoče pričakovati ob raziskavi drugih folklornih žanrov.

\section{Večerna molitev}

Zadnji primer sodi v folklorni žanr nabožnih pesmi, kamor se uvrščajo molitvene pesmi ali molitve. Zaradi ritmizirane oblike pa kaže posebnosti v razmerju med narečnostjo in nadnarečnostjo. 


\section{Vəčerna mulitu}

Pejmo spat, Bo $\gamma$ je zvat,

pejmo yledat, kaj Marija dela.

Marija na zwatmo stoučka sadi,

nebeške dušice napaja,

jah u svet rej pusaja.

Do b še naše duše napojiva,

jah u svet rej pusadiva,

Jezus Kristus, amen.

Jezus pa Marija sta rekwa, do lečt,

trdu zaspat, onkoyar se bat,

tri nebeške angalčke $k$ nom pusvat.

Paru nas bo vižou, drug bo špižou,

trek bo varvou mojo ubojo dušo in telo. Amen.

Pejmo spat, Bor je zvat,

pejmo yledat, kaj Marija dela.

Marija na zwatmo stoučka sadi, nebeške dušice napaja,

joh u svet rej pusaja.

Da b še naše duše napojiva,

jah u svet rej pusadiva,

Jezus Kristus, amen.

Jezus pa Marija sta rekla, do lečt,

trdu zaspat, ankoyar se bat,

tri nebeške angalčke h nam pusvat.

Paru nas bo vižou, drug bo špižou,

trek bo varvou mojo uboyo dušo in telo. Amen.

(Arhiv GNI, št. digit. mesta MZ000003, Kamniška Bistrica, posnela: Marija Klobčar, 28. 1. 2019, transkripcija besedila: Anja Moric in Marjetka Golež Kaučič).

V ritmiziranem besedilu se pokaže narečni izgovor, ker ni melodije, ki bi ga omejevala. Med izrekanjem molitve je izražen intimni odnos, razmerje med človekom in transcendenco, gre za ritualno izrekanje. Kljub svetosti besedila ritem narekuje zelo iskren in čustven odnos, ki je lahko naraven le z naravno izreko, z narečjem, ki ga uporablja govorec.

Informatorka je za to molitev povedala: "To j pa večerna mulitev... Mogoče je zna še kakšn pa juprašañe... Na velk petek pa od sv. petka... Tisto pa velikrat se spomnam tkole zvečer, ka greva spat pa [s hčerko] molva." 
$S$ posnetka (govor ni bil transkribiran) lahko razberemo, da se je zgodila jezikovna konvergenca ali prilagajanje informatorki, saj se je spraševalka, ki je z istega narečnega območja, govorno prilagodila pripovedovalki. Uporabila je način govora, značilen za Kamniško Bistrico oziroma za gorenjsko narečje. To ni bilo narejeno prilagajanje, temveč popolnoma naravno, kar potrjuje našo tezo, da tudi raziskovalci - upoštevaje govorni in družbeni položaj - lahko preklapljajo iz knjižnega koda v narečje.

\section{SKLEP}

$\mathrm{V}$ vsakem folklornem dogodku, $\mathrm{v}$ katerem odkrivamo preklapljanje iz enega jezikovnega koda v drugega, gre za izbor različnih komunikacijskih praks: pesem, ki je sinkretična celota melodije in besedila ter ritma in ritmične sheme, je besedilno bolj naslonjena na knjižni kod, medtem ko je pogovor o kontekstu pesmi, o šegah, funkciji, oblikovanju in drugem mnogo bolj naslonjen na narečni kod.

Narečnost in nadnarečnost folklore tako postavljamo $\mathrm{v}$ enakovredne podsisteme besednega ustvarjanja: ne gre torej le za socialno zvrst, temveč tudi za funkcionalno in umetnostno zvrst, ki v pomenski in zvočni strukturi nosi posebnosti in identiteto nekega mikrokozmosa. Narečje (pogovorni jezik) je prvotni idiom, ki najbolj prepričljivo ubeseduje človekov notranji svet in odseva zunanjega. $Z$ njim je vpetost v lokalno identiteto mnogo obsežnejša in odseva tudi v folklori, kar pritrjuje intrinzični povezanosti narečja in folklore, kljub njeni nadnarečnosti. Jezik v ljudski pesmi namreč ni čisto narečje, saj je ljudska pesem umetnostni žanr, ki hromi uporabo čistega narečja. Posebej pa preklop v nadnarečje povzročata ali kar narekujeta ritem in melodija pete. Tudi pisni kod pesmaric, ki jih pevci uporabljajo za spominsko oporo, kaže, da se tudi v folklori dogajajo hitri preklopi iz enega jezikovnega koda v drugega, celo tretjega. Velikokrat je to spontano, tu in tam pa zavestno. Jezikovni položaji v folklornem dogodku, zaznani na ravnini med pevcem in spraševalcem, se spreminjajo v načinih posredovanja folklore - v petju in govoru. Pri slednjem sta udeleženca v medsebojni komunikaciji, ki je enkrat enosmerna, drugič dvosmerna. Informator je v govoru na primarni jezikovni ravnini in lokalni identiteti, v petju pa prehaja na sekundarno raven, približuje se standardu, a še vedno ohranja nekaj narečnih besed, ki kažejo na nadnarečnost ali povezavo lokalnega z nacionalnim. Raba narečja ali nadnarečja je tako povezana s folklornim žanrom, s sinkretizmom tega žanra (besede + melodija), pa tudi s specifičnostjo folklornega dogodka, ki ni nastop pred občinstvom, temveč petje za spraševalca in govor lastnih spominov in opisovanj konteksta tega dogodka za znanstvene namene. Večinoma ne gre za spontani dogodek, temveč za predpripravo zanj, še posebej takrat, kadar informator uporablja tudi pisno predlogo (rokopisne pesmarice), zato je preklapljanje jezikovnih kodov tudi zavestno. Le emotivni spomini in življenjske zgodbe, ki jih informator spontano deli s spraševalcem, ustvarjajo izrazito spontanost v govoru. Narečna beseda v nadnarečni pesmi je opaznejša in lahko povzroči tudi semantično razliko, če jo raziskovalec opazi in pozna 
njen pomen. Preučevanje folklore (ljudske pesmi) in njenih jezikovnih, vsebinskih, zvočnih, emotivnih in socialnih značilnosti lahko odgovori na vprašanje, ali lahko mislimo folkloro na različnih ravneh, tudi takih, ki do zdaj niso bili običajni.

\section{REFERENCE}

Abrahams, Roger D., ur. 1970. A Singer and Her Songs: Almeda Riddle's Book of Ballads. Baton Rouge: Lousiana State University Press.

Auer, Peter. 1998. Dialect Leveling and the Standard Varietes in Europe. Folia Linguistica 32 (1-2): 1-9. DOI: https://doi.org/10.1515/flin.1998.32.1-2.1.

Auer, Peter. 2002. Introduction: Bilingual Conversation Revisited. V Code Switching in Conversation: Language, Interaction and Identity, ur. Peter Auer, 1-24. London, New York: Routledge.

Auer, Peter in Frans Hinskens. 1996. The Convergence and Divergence of Dialects in Europe: New and Not so New Developments in an Old Area. Sociolinguistica 10: 1-25. DOI: https://doi. org/10.1515/9783110245158.1.

Auer, Peter, Frans Hinskens in Paul Kerswill, ur. 2005. Dialect Change: Convergence and Divergence in European Languages. Cambridge, New York: Cambridge University Press.

Austin, John. 1990 (1962). Kako napravimo kaj z besedami. Ljubljana: Studia Humanitatis.

Babcock, Barbara. 1978. The Story in the Story: Metanarration in Folk Narrative. V Verbal Art as Performance, ur. Richard Bauman, 61-80. Prospect Heights: Waveland Press.

Bauman, Richard. 1971. Differential Identity and the Social Base of Folklore. Journal of American Folklore 84 (331): 31-41. DOI: https://doi.org/10.2307/539731.

Bauman, Richard. 1975. Verbal Art as Performance. American Anthropologist 77 (2): 290-311. https:// www.jstor.org/stable/674535.

Bauman, Richard. 2002. Disciplinarity, Reflexivity, and Power in Verbal Art as Preformance: A Response. Journal of American Folklore 115 (455): 92-98. DOI: https://doi.org/10.2307/542080.

Bauman, Richard in Charles Briggs. 1990. Poetics and Performance as Critical Perspectives on Language and Social Life. Annual Review of Anthropology 19:59-88. DOI: https://doi.org/10.1146/annurev. an.19.100190.000423.

Bausinger, Hermann. 1977.Zur kulturalen Dimension von Identität. Zeitschrift für Volkskunde 73: 210-215.

Bitenc, Maja. 2016. Zjezikom na poti med Idrijskim in Ljubljano. Ljubljana: Znanstvena založba Filozofske fakultete.

Bitenc, Maja in Karmen Kenda-Jež, 2015. Language Variation in Slovene: A Case Study of Two Geographically Mobile Speakers. V Language Variation - European Perspectives 5, ur. Eivind Torgersen idr., 31-42. Amsterdam, Philadelphia: John Benjamins Publishing Company.

Blom, Jan-Peter in John J. Gumperz. 1986 (1972). Social Meaning in Linguistic Structure: Code-Switching in Norway. V Directions in Sociolinguistics: The Ethnography of Communication, ur. John J. Gumperz in Dell Hymes, 407-434. Oxford, New York: Basil Blackwell.

Boas, Franz. 1925. Stylistic Aspect of Primitive Literature. Journal of American Folklore 38: 329-339. DOI: https://doi.org/10.2307/535235.

Botkin, Benjamin Albert. 1949. A Treasury of Southern Folklore. New York: Crown Publishers. 
Brown, Penelope in Stephen Levinson. 1978. Politeness: Some Universal in Language Usage. Cambridge: Cambridge University Press.

Castells, Manuel. 2010. The Power of Identity. Malden: Willey-Blackwell.

Duličenko, Aleksander Dmitrijevič. 1981. Slavianskije literaturnyje mikrojazyki: Voprosy formirovanija $i$ rasvitija. Tallinn.

Dundes, Alan. 1984. Defining Identity through Folklore: Abstract. Journal of Folklore Research 21 (2-3): 149-152. https://www.jstor.org/stable/3814550.

Dundes, Alan. 2005. Reply to Michael Evans. American Folklore Society News 34 (1): 14.

Edwards, John. 2009. Language and Identity. New York: Cambridge University Press.

Fine, Isabelle. 1983. In Defence of Literary Dialect: A Response to Dennis R. Preston. The Journal of American Folklore 96 (381): 323-330. DOI: https://doi.org/10.2307/540948.

Finnegan, Ruth. 1969. How to Do Things with Words: Performative Utterances among the Limba of Sierra Leone. Man 4: 537-552. DOI: https://doi.org/10.2307/2798194.

Foley, William. 1997. Anthropological Linguistics: An Introduction. Malden: Blackwell.

Gardner-Chloros, Penelope. 2009. Code-Switching. Cambridge, New York: Cambridge University Press. DOI: https://doi.org/10.1017/CBO9780511609787.

Giddens, Anthony. 1991. Modernity and Self-Identity: Self and Society in the Late Modern Age. Cambridge: Polity Press.

Glassie, Henry. 1982. Passing the Time: Folklore and History of an Ulster Community. Dublin: O'Brien.

Golež Kaučič, Marjetka. 2001. Raziskovalne metode v folkloristiki - med tradicionalnim in inovativnim. Traditiones 30 (1): 279-291. http://www.dlib.si/?URN=URN:NBN:SI:DOC-UCLMJXU5.

Golež Kaučič, Marjetka. 2020. Singing the Other: Singing in Two Languages and Code-Switching/ Stitching. Tautosakosdarbai 59: 100-119. http://www.llti.lt/failai/TD59_spaudai_internetine\%20 versija-84-103.pdf.

Gossen, Gary. 1978. Chamula Genres of Verbal Behavior. V Verbal Art as Performance, ur. Richard Bauman, 81-116. Prospect Heights: Waveland Press.

Gumperz, John. 1977. The Sociolinguistic Significance of Conversational Code-Switching. RELCJournal 8 (2): 29-38. DOI: https://doi.org./10.1177/003368827700800201.

Halbwachs, Maurice. 2001 (1950). Kolektivni spomin. Ljubljana: Studia Humanitatis.

Hanks, William F. 1987. Discourse Genres in a Theory of Practice. American Ethnologist 14: 668-692. https://www.jstor.org/stable/645320.

Helms, Janet. 1994. The Conceptualization of Racial Identity and Other Racial Constructs. V Human Diversity: Perspectives on People in Context, ur. J. Edison idr., 181-198. San Francisco: Jessey Bass.

Hinskens, Frans, Peter Auer in Paul Kerswill. 2005. The Study of Dialect Convergence and Divergence: Conceptual and Methodological Considerations. V Dialect Change: Convergence and Divergence in European Languages, ur. Peter Auer idr., 1-48. Cambridge: Cambridge University Press. DOI: https://doi.org/10.1017/CBO9780511486623.003.

Hobsbawm, Eric J. in Terence Ranger. 2003 (1983). The Invention of Tradition. Cambridge: Cambridge University Press.

Honko, Lauri. 1980. Upptackten av Gfolkdiktning och nationeell identitet i Finland. Tradisijon 10:33-51. 
Hughes, Arthur, Peter Trudgill in Dominic Watt. 2005. English Accents and Dialects: An Introduction to Social and Regional Varieties of English in the British Isles. London: Hodder Education.

Hymes, Dell. 1971. The Contribution of Folklore to Sociolinguistic Research. Journal of American Folklore 84: 42-50. https://www.jstor.org/stable/539732.

Hymes, Dell. 1975. Folklore's Nature and the Sun's Myth.Journal of American Folklore 88: 346-369. DOI: https://doi.org/10.2307/538651.

Hymes, Dell. 1986 (1972). Models of the Interaction of Language and Social Life. V Directions in Socioloingustics: The Ethnography of Communication, ur. John J. Gumperz in Dell Hymes, 35-71. Oxford, New York: Basil Blackwell.

Ivančič Kutin, Barbara. 2011. Živa pripoved v zapisu: Kontekst, tekstura in prekodiranje pripovedi Tine Kravanja iz Bavšice. Ljubljana: Založba ZRC, ZRC SAZU.

Jakop, Tjaša. 2007. Dialektološke analize izbranih tipov pesmi. V Slovenske ljudske pesmi 5, ur. Marjetka Golež Kaučič idr., 895-904. Ljubljana: Založba ZRC, ZRC SAZU, Slovenska matica.

Jakop, Tjaša, 2019. Narečno v javnem. V Slovenski javni govor in jezikovno-kulturna (samo)zavest, ur. Hotimir Tivadar, 205-211. Ljubljana: Znanstvena založba Filozofske fakultete. https://centerslo. si/wp-content/uploads/2019/10/Obdobja-38_Jakop.pdf.

Johnstone, Barbara in William Marcellino. 2011. Dell Hymes and the Ethnography of Communication. V The SAGE Handbook of Sociolinguistics, ur. Ruth Wodak, Barbara Johnstone in Paul Kerswill, 57-66. Los Angeles (idr.): SAGE.

Kenda-Jež, Karmen. 2002. Cerkljansko narečje: Teoretični model dialektološkega raziskovanja na zgledu besedišca in glasoslovja. Doktorska disertacija. Ljubljana: Filozofska fakulteta Univerze v Ljubljani.

Kenda-Jež, Karmen. 2011. Fonetična transkripcija. V Slovenski lingvistični atlas 1: Človek (telo, bolezni, družina), ur. Jožica Škofic. Ljubljana: Založba ZRC, ZRC SAZU.

Kodrič, Karmen Brina in Hotimir Tivadar. 2015. Instrumentalna fonetična analiza pétih samoglasnikov in pravorečje popularnega pétega besedila popevke. Muzikološki zbornik 52 (1): 147-169.

Kumer, Zmaga. 1996. Vloga, zgradba, slog slovenske ljudskepesmi. Ljubljana:Založba ZRC SAZU,ZRC SAZU.

Kumer, Zmaga. 2002. Slovenska ljudska pesem. Ljubljana: Slovenska matica.

Labov, William. 1966. The Linguistic Variable as a Structural Unit. Washington Linguistic Review 3: 4-22. https://eric.ed.gov/?id=ED010871.

Labov, William. 2013. The Language of Life and Death: The Transformation of Experience in Oral Narrative. Cambridge: Cambridge University Press.

Labov, William in Johua Waletzky. 1967. Narrative Analaysis: Oral Versions of Personal Experience. V Essays on the Verbal and Visual Arts, ur. June Helm, 12-44. Seattle: University of Washington Press.

Le Page, Robert. 2008 (1997). The Evolution of a Sociolinguistic Theory of Language. V The Handbook of Sociolinguistics, ur. Florian Coulmas, 15-32. Malden, Oxford, Carlton: Blackwell Publishing.

Le Page, Robert in Andrea Tabouret-Keller. 1985. Acts of Identity. Cambridge: Cambridge University Press.

List, George. 1963. The Boundaries of Speech and Song. Ethnomusicology 7: 1-16. DOI: https://doi. org/10.2307/924141.

McDonald, Maryon. 1986. Celtic Ethnic Kinship and the Problem of Being English. Current Anthropology 27 (4): 333-341. https://www.jstor.org/stable/2743049.

McDowell, John Holmes. 1979. Children Riddling. Bloomington: Indiana University Press. 
McDowell, John Holmes. 1985. The Poetic Rites of Conversation. Journal of Folklore Resarch 22: 113-132. https://www.jstor.org/stable/3814388.

McDowell, John Holmes. 2018. Folklore and Sociolinguistics. Humanities 7 (9): 1-12. DOI: https://doi. org/10.3390/h7010009.

Meyerhoff, Miriam. 2011. Introducing Sociolinguistics. London, New York: Routledge.

Omdal, Helga. 1995. Attitudes Toward Spoken and Written Norwegian. International Journal of the Sociology of Language 115: 85-106. DOI: https://doi.org.10.1515/ijsl.1995.115.85.

Phinney, Jean. 1991. Ethnic Identity and Self-Esteem: A Review and Integration. Hispanic Journal of Behavioral Sciences 13 (2): 193-208. DOI: https://doi.org/10.1177/07399863910132005.

Pound, Louise. 1945. Folklore and Dialect. California Folklore Quarterly 4: 146-153. https://www.jstor. org/stable/1495677.

Pound, Louise. 1989. Nebraska Folklore. Lincoln, London: University of Nebraska Press.

Pristley, Tom in Ruxanda Conamaru. 2009. Identity among the Minority Slovenes of Carinthia, Austria. Razprave in gradivo 58:6-23. https://www.sistory.si/cdn/publikacije/1-1000/811/Razprave_in_gradiva-58.pdf.

Robertson, Roland. 1995. Glocalization: Time-Space and Homogeneity-Heterogeneity. V Global Modernities, ur. Mike Featherstone idr., 25-44. London: Sage.

Røyneland, Unn. 2009. Dialect in Norway - Catching Up with Rest of Europe. Journal of the Sociology of Language. 1-26. https://doi.org/10.1515/IJSL.2009.015.

Russel, Ian, ur. 1986. Singer, Song and Scholar. Scheffield: Scheffield Academic Press.

Rusell, Ian. 2006. Working with Tradition: Towards a Partnership Model of Fieldwork. Folklore 117 (1): 15-32. https://www.jstor.org/stable/30035319.

Sahlins, Marshall. 1999 (1972). Ekonomika kamene dobe. Ljubljana: Založba *cf.

Salzmann, Zdenek. 1998. Language, Culture and Society: An Introduction to Linguistic Anthropology. Boulder: Westview Press.

Saville-Troike, Muriel. 2004. Anthropological Linguistics and the Ethnography of Speaking. V Sociolinguistics / Soziolinguistik: Vol. 1, ur. Ulrich Ammon idr., 109-120. Berlin, New York: Walter de Gruyter. DOI: https://doi.org/10.1515/9783110141894.1.1.109.

Sherzer, Joel. 1978. Cuna Ikala: Literature in San Blas. V Verbal Art as Performance, ur. Richard Bauman, 133-150. Prospect Heights: Waveland Press.

Sherzer, Joel. 1983. Kuna Ways of Speaking: An Ethnographic Perspective. Austin: University of Texas Press.

SLP 4. 1998. Slovenske ljudske pesmi: Četrta knjiga: Pripovedne pesmi. Ljubezenske, ur. Marjetka Golež idr. Ljubljana: Založba ZRC, ZRC SAZU.

Smith, Anthony D. 2005. Nationalism in Early Modern Europe. History and Theory 44 (3): 404-415. https://www.jstor.org/stable/3590824.

Stanford, James N. 2007. Dialect Contact and Identity. Ann Arbor: Michigan University Press.

Stanford, James N. 2008. A Socionetic Analysis of Sui Dialect Contact. Language Variation and Change 20 (3): 293-309. DOI: https://doi.org/10.1017/S0954394508000161.

Stanonik, Marija. 2001. Teoretični oris slovstvene folklore. Ljubljana: ZRC SAZU.

Stanonik, Marija. 2007. Slovenska narečna književnost. Maribor: Slavistično društvo.

Šabec, Nada. 1995. Halfpa pu: The Language of Slovene Americans. Ljubljana: ŠKUC. 
Šabec, Nada. 1997. Slovene-English Language Contact in the USA. International Journal of the Sociology of Language 124: 129-183. DOI: https://doi.org/10.1515/ijsl.1997.124.129.

Šabec, Nada. 2016. Med tradicionalnim in sociolingvističnim pristopom k preučevanju jezikovne variabilnosti. V Rojena v narečje: Akademikinji prof.dr. Zinki Zorko ob 80-letnici, ur. Marko Jesenšek idr., 656-670. Maribor: Mednarodna založba Oddelka za slovanske jezike in književnosti, Filozofska fakulteta.

Šekli, Matej. 2015. Slovanski knjižni mikrojeziki: Opredelitev in prikaz pojava znotraj slovenščine. V Država in narod v slovenskem jeziku, literaturi in kulturi, ur. Hotimir Tivadar, 93-100. Ljubljana: Znanstvena založba Filozofske fakultete. https://centerslo.si/knjige/gradiva/ seminarski-in-simpozijski-zborniki/51-ssjlk-2015/51-ssjlk.

Tedlock, Barbara. 1991. From the Participant Observation to the Observation of Participation: The Emergence of Narrative Ethnography. Journal of Anthropological Research 47 (1): 69-94. https:// www.jstor.org/stable/3630581.

Toelken, Barre. 1996. From Entertainment to Realization in Navajo Filedwork. V The World Observed: Reflections on the Fieldwork Process, ur. Bruce Jackson in Edward D. Ives, 1-17. Urbana, Chicago: University of Illions Press.

Trudgill, Peter. 1986. Dialects in Contacts. Oxford: Blackwell.

Ule, Mirjana. 2009a. Psihologija komuniciranja in medosebnih odnosov. Ljubljana: Fakulteta za družbene vede, Založba FDV.

Ule, Mirjana. 2009b. Socialna psihologija: Analitični pristop k življenju v družbi. Ljubljana: Fakulteta za družbene vede, Založba FDV.

Uppsala Institute for Dialect and Folklore Research. 1961. https://openfolklore.org/content/ institute-dialect-and-folklore-research-uppsala-sweden.

van Dijk, Teun A. 1977. Text and Context: Explorations in the Semantics and Pragmatics of Discourse. London: Longman.

van Dijk, Teun A., 2008. Discourse and Context: A Socio-Cognitive Approach. Cambridge: Cambridge University Press.

Vandekerckhove, Reinchild in David Britain. 2009. Dialects in Western Europe: A Balanced Picture of Language Death, Innovation, and Change. Intl.J. Lang 196/197: 1-6. DOI: https://doi.org/10.1515/ IJSL.2009.014.

Voigt, Vilmos. 1995. Folklore, Dialectology, and Geolinguistics. Traditiones 24: 353-367. http://www.dlib. si/?URN=URN:NBN:SI:DOC-M7B64GTZ.

Watt, Dominic idr. 2010. Language and Identities. Edinburgh: Edinburgh University Press.

Watts, Richard J. 2010. Using Folk Songs as a Source for Dialect Change?: The Pervasive Effects of Attitudes. Multilingua 29 (3-4): 307-335. DOI: https://doi.org/10.1515/mult.2010.015.

Widdowson, John D. A. 2012 [1987]. English Dialects and Folklore: A Neglected Heritage. Folklore 98 (1): 41-52. DOI: https://doi.org/10.1080/0015587X.1987.9716394.

VIRI

GNI M 43. 447. Samomor nune, GNI T 1433, Mostec pri Dobovi, 14. 11. 1986. Glasbenonarodopisni inštitut ZRC SAZU, Zvočni arhiv. Ljubljana: GNI ZRC SAZU. 
GNI št. digitalnega mesta MZ000003. Molitev. Kamniška Bistrica. 28.1.2010. Glasbenonarodopisni inštitut ZRC SAZU, Zvočni arhiv. Ljubljana: GNI ZRC SAZU.

GNI TZ JS 4. Glasbenonarodopisni inštitut ZRC SAZU, Terenski zvezek JS 4. Ljubljana: GNI ZRC SAZU, 121-124.

\section{LANGUAGE OF SPEECH, LANGUAGE OF SONG: BETWEEN DIALECT, SUPRA-DIALECT AND STANDARD LANGUAGE}

The article addresses the issue of dialect and supra-dialect of a folk song as a textual problem related to the texture (melody) of the text, thus trying to determine whether it is a transition from pronounced dialect to supra-dialect, which is a spontaneous or conscious decision of the bearers for an intermediate stage between dialect and literary language due to a change in language position and entry into an artistic genre. In choosing communication practice right in this event, we can also identify self-censorship of an individual who believes that when he enters the environment of a song, he also enters a higher linguistic and aesthetic and cultural environment, such as his native dialect, and therefore switches to the supra-dialect. Last but not least, bearer also use the transition from oral to written, when they also use handwritten songbooks while singing, which further strengthens the supra-dialect. We first find out how we can connect folklore with dialect and ways of transition from pure dialect to more literary forms, where there is a distinct duality between pure dialect in spoken word and reduction of dialect in singing and transition from dialect to supra-dialect, which is not yet literary language. We find out how singers from different places and geographical areas use dialect words according to the rhythm and melody and the connection between dialect and supra-dialect and the content of a folklore text or event. We find out how singers from different places and geographical areas use dialect words according to the rhythm and melody and the connection between dialect and supra-dialect and the content of a folklore text or event. In this way, we also shed light on the importance of the dialect for the identity of the individual and the community, which is local and national. At the same time, we determine the spontaneous and conscious use of a dialect or super-dialect according to the social situation. A dialect word in a supra-dialect poem is much more visible than in a dialect poem, it can also cause a semantic difference, of course if we recognize it and know its meaning. Language and content are interrelated, and at the same time, each social situation influences the linguistic code changes in a folklore event. The study of folklore (folk songs) and its linguistic, content, sound, emotional and social characteristics can answer the question of whether we can think offolklore on different levels, even those that have not been common until now.

Prof. dr. Marjetka Golež Kaučič, ZRC SAZU, Glasbenonarodopisni inštitut, marjetka.golez-kaucic@zrc-sazu.si 
Prispevek je nastal v raziskovalnem projektu J7-9426 Misliti folkloro: Folkloristične, etnološke in računske perspektive in pristopi $k$ narečju, ki ga je sofinancirala Javna agencija za raziskovalno dejavnost Republike Slovenije iz državnega proračuna. 